\title{
PENGARUH JARAK TANAM TERHADAP PRODUKTIVITAS INDIGOFERA (Indigofera zolingeriana) DI AREAL TERBUKA
}

\author{
Wemiles Morip, S. D. Anis", M. M. Telleng, C. I. J. Sumolang \\ Fakultas Peternakan Universitas Sam Ratulangi, Manado, 95115
}

\begin{abstract}
ABSTRAK
Penelitian ini bertujuan untuk mengetahui produktivitas legum Indigofera zollingeriana yang ditanam di areal terbuka sekitar perkebunan kelapa dengan jarak tanam yang berbeda. Penelitian ini menggunakan Rancangan Acak Lengkap (RAL) dengan 3 perlakuan yang terdiri dari $\mathrm{J} 1$ : jarak tanam $1,0 \mathrm{~m} \times 0,5 \mathrm{~m}, \mathrm{~J} 2$ : jarak tanam 1,0 m x 1,0 m, dan J3: jarak tanam $1,0 \mathrm{~m} \times 1,5 \mathrm{~m}$, masing-masing perlakuan terdiri dari 6 ulangan. Variabel yang diukur adalah produktivitas tanaman yaitu berat segar batang, berat bahan kering batang, berat segar daun dan berat bahan kering daun. Hasil analisis menunjukkan bahwa perlakuan jarak tanam memberikan pengaruh yang berbeda sangat nyata $(\mathrm{P}<0,01)$ terhadap berat segar batang, berat bahan kering batang, berat segar daun dan berat bahan kering daun tanaman indigofera. Hasil uji beda nyata jujur menunjukkan bahwa jarak tanam $1,0 \mathrm{~m} \mathrm{x}$ 1,5 m menghasilkan berat segar batang, berat bahan kering batang, berat segar daun dan berat bhan kering daun yang lebih tinggi dibandingkan dengan jarak tanam $1,0 \mathrm{~m} \times 1,0 \mathrm{~m}$ dan jarak tanam $1,0 \mathrm{~m} \times 0,5 \mathrm{~m}$. Disimpulkan bahwa jarak tanam 1,0 m x 1,5 $\mathrm{m}$ memberikan produktivitas tertinggi dengan menghasilkan berat segar batang, berat bahan kering batang, berat segar daun, berat bahan kering daun tanaman indigofera yang tertinggi.
\end{abstract}

Kata Kunci : Kepadatan, Indigofera, jarak tanam, produktivitas.

*Korespondensi (corresponding author):

Email: selvie-anis@yahoo.com

\section{ABSTRACT}

\section{THE EFFECT OF PLANTING SPACE ON PRODUCTIVITY OF INDIGOFERA (Indigofera zollingeriana) IN FULL SUN AREA. The purpose of this} research was determines the productivity of Indigofera zollingeriana with three different planting space. This experiment was conducted using Completely Randomized Design (CRD). The treatment consisted of three planting space, (1) $1.0 \mathrm{~m}$ x $0.5 \mathrm{~m}$, (2) $1.0 \mathrm{~m} \mathrm{x} 1.0 \mathrm{~m}$, and (3) $1.0 \mathrm{~m} \mathrm{x}$ $1.5 \mathrm{~m}$, each treatment had six replications. Data were analyzed using analysis of variance and HSD test. The variables measured were fresh and dried stem weight, fresh and dried leaf weight. The results showed that planting space were significant different $(\mathrm{P}<0.01)$ on fresh and dried stem weight, fresh and dried leaf weight. HSD test showed that planting space $1.0 \mathrm{~m} \times 1.5$ $\mathrm{m}$ were significant $(\mathrm{P}<0.01)$ have higher stem fresh weight, stem dry matter weight, fresh leaf weight and leaf dry matter weight than planting space $1.0 \mathrm{~m} \mathrm{x} 1.0 \mathrm{~m}$ and 1.0 $\mathrm{m} \times 0.5 \mathrm{~m}$. It can be concluded that planting space $1.0 \mathrm{~m} \times 1.5 \mathrm{~m}$ have the highest productivity that were highest stem freshweight, stem dry matter weight, leaf freshweight and leaf dry matter weight.

Key words: Indigofera zollingeriana, planting space, productivity 


\section{PENDAHULUAN}

Di Indonesia ternak ruminansia memiliki peranan yang sangat penting dalam memenuhi kebutuhan daging nasional. Kebutuhan daging nasional sebagian besar merupakan kontribusi dari peternakan rakyat dan kekurangannya dipasok dari luar negeri sebagai komoditi impor. Permasalahan yang dihadapi peternak saat ini adalah rendahnya produktivitas ternak sebagai dampak dari rendahnya kualitas dan kuantitas hijauan pakan. Rendahnya produktivitas ternak potong disebabkan karena status nutrisi dan suplai hijauan sepanjang tahun yang rendah pada musim kemarau, terutama di daerah kering wilayah Timur Indonesia.

Rendahnya kualitas pakan ditandai dengan tingginya kandungan serat kasar sehingga zat-zat makanan essensial seperti protein, energi dan mineral menjadi kurang tersedia untuk kebutuhan ternak. Penyediaan hijauan pakan yang berkualitas mutlak diperlukan dalam rangka meningkatkan produksi dan produktivitas ternak ruminansia (Telleng et al., 2016). Untuk dapat memenuhi kebutuhan protein dan energi dibutuhkan suplai sumber protein yang murah dan mudah didapat. Salah satu hijauan yang dapat dikembangkan sebagai sumber pakan yaitu Indigofera zollingeriana. Tanaman legume pohon inimerupakan salah satu tanaman pakan ternak yang memiliki kandungan nutrisi dan produksi yang tinggi, potensial sebagai bahan pakan dan mampu meningkatkan produktivitas ternak (Telleng et al., 2017), bahkan ketika ditumpang sari dengan sorgum menghasilkan produksi bahan kering sebesar 8,2 ton/ha (Telleng et al., 2016), serta sangat toleran terhadap kondisi tanah kering, genangan air, tanah berkadar garam tinggi (saline) dan tanah masam.

Faktor-faktor yang mempengaruhi pertumbuhan tanaman adalah faktor genetik (faktor dalam) dan faktor lingkungan (faktor luar). Salah satu faktor lingkungan adalah jarak tanam atau tingkat kepadatan. Tingkat kepadatan yang tinggi atau jarak tanam yang dekat akan membatasi kemampuan tampung luasan tanah yang dapat dimanfaatkan oleh setiap individu tanaman, karena akan terjadi persaingan unsur hara, air dan cahaya matahari. Rasio daun/batang pada leguminosa pohon sangat penting karena organ metabolisme utama adalah daun, semakin tinggi jumlah daun maka kualitas tanaman tersebut makin baik (Telleng, 2017). Informasi awal jenis ini tumbuh baik pada umur pemotongan 12 minggu di areal perkebunan kelapa (Anis et al., 2019), tetapi respons tanaman ini terhadap manajemen penanaman berupa kepadatan populasi pada lingkungan terbuka belum pernah dilaporkan. Untuk itulah penelitian 
ini dilaksanakan untuk mempelajari bagaimana produksi Indigofera zollingeriana pada ber bagai tingkat kepadatan populasi tanaman di areal terbuka tanpa naungan.

\section{MATERI DAN METODE} PENELITIAN

\section{Waktu dan Tempat Penelitian}

Penelitian ini telah dilaksanakan dikebun percobaan milik Balai Pengkajian Teknologi Pertanian (BPTP) yang terletak didesa Talawaan Bantik, Kecamatan Wori, Kabupaten Minahasa Utara.

\section{Bahan dan Alat yang di gunakan}

Alat-alat yang digunakan berupa:Timbangan, Alat tulis, Kamera,Spidol, Cutter, Meter, Nampan, Pollybag, Pisau dan Tali Plastik.

\section{Rancangan Penelitian}

Rancangan yang digunakan adalah Rancangan Acak Lengkap (RAL) (Steel and Torrie, 1995), 3 perlakuan dengan masing-masing perlakuan diulang sebanyak 6 kali sehingga terdapat 18 satuan percobaan. Model rancangan percobaan adalah:

$\mathbf{Y}_{\mathrm{ij}}=\boldsymbol{\mu}+\tau_{\mathrm{i}+} \boldsymbol{\Sigma}_{\mathrm{ij}}$

Keterangan :

$\mathbf{Y}_{\mathbf{i j}}=$ Variabel yang akan dianalisis pada perlakuan ke-i ulangan ke-j

$\boldsymbol{\mu} \quad=$ Rata-rata (nilai tengah populasi)

$\boldsymbol{\tau}_{\mathbf{i}} \quad=$ Pengaruh perlakuan ke-i
$\Sigma_{\mathrm{ij}} \quad=$ Galat percobaan pada perlakuan ke-i ulangan ke-j

Perlakuan terdiri dari 3 jarak tanam yaitu:

$\mathrm{J}_{1}: 1,00$ meter $\mathrm{x} 0,50$ meter

$\mathrm{J}_{2}: \quad 1,00$ meter $\mathrm{x} \quad 1,00$ meter

$\mathrm{J}_{3}: 1,00$ meter $\mathrm{x} 1,50$ meter

Perlakuan ditempatkan secara acak pada petak percobahan yang berukuran 4 meter x 3 meter untuk tiap perlakuan yang diuji. Perlakuan diletakan secara acak sebagaimana terlihat pada Gambar 1.

\begin{tabular}{|l|l|l|l|l|l|}
\hline J3U3 & J2U5 & J1U2 & J1U6 & J3U1 & J2U4 \\
\hline J1U3 & J3U5 & J2U2 & J3U6 & J2U1 & J1U4 \\
\hline J2U3 & J1U5 & J3U2 & J2U6 & J1U1 & J3U4 \\
\hline
\end{tabular}

Gambar 1. Bagan Pengacakan Perlakuan

\section{Variabel yang diukur}

1. Produksi daun segar

Produksi daun segar (gram/tanaman) I. zollingeriana, diperoleh dari rataan produksi segar daun per tanaman percobaan.

2. Produksi batang segar

$$
\text { Produksi batang segar }
$$
(gram/tanaman) I. zollingeriana, diperoleh dari rataan produksi segar batang per tanaman percobaan.

3. Produksi bahan kering daun

Produksi bahan kering daun (gram/tanaman) merupakan hasil 
perkalian antararataan produksi segar daun dengan kandungan bahan kering daun $(\%)$.

4. Produksi bahan kering batang

Produksi bahan kering batang (gram/tanaman) merupakan hasil perkalian antara produksi segar batang dengan kandungan bahan kering batang (\%).

\section{Prosedur Penelitian}

Tahapan penelitian ini adalah sebagai berikut:

1. Pengolahan tanah

Sebelum pengolahan tanah, terlebih dahulu dilakukan pembersihan lahan (land clearing), setelah bersih dilakukan pengolahan tanah dengan traktor untuk memecahkan lapisan tanah menjadi bongkahan-bongkahan, dibiarkan selama dua minggu. Selanjutnya tanah digemburkan dengan menggunakan Rotary sehingga menjadi struktur yang remah, sekaligus membersihkan sisa-sisa perakaran gulma.

2. Pembuatan petak percobaan

Petak percobaan dilakukan disesuaikan dengan kondisi lahan, dan dibentuk petak percobaan sesuai kebutuhan untuk ditempatkan perlakuan sesuai disain percobaan, terdiri dari 18 petak masingmasing berukuran $4 \mathrm{~m} \mathrm{x} 3 \mathrm{~m}$, dengan jarak antar petak 1,0 m.

3 Penyiapan bibit dan penanaman

Bibit Indigofera zollingeriana diperoleh dari laboratorium Agrostologi
Fakultas Peternakan IPB.Penanaman $I$. zollingeriana dimulai dengan persemaian di tempat semai (seeding tray atau baki kecambah) yang berisi tanah dan kompos dengan perbandingan $1: 1$. Benih langsung ditabur secara merasa ke permukaan tanah dalam baki kecambah tertsebut.. Penyiraman dilakukan hati-hati agar kecambah tidak rusak dan tidak tergenang. Hari ke 7-10 setelah tumbuh tanaman dipindahkan ke poly bag ukuran $0,5 \mathrm{~kg}$ masing-masing diisi satu tanam $I$. zollingeriana sampai umur 8 minggu. Tanaman kemudian dipindahkan kepetak percobaan yang telah diolah. Penanaman Indigofera zollingeriana di lahan dilakukan sesuai dengan perlakuan jarak tanam (Abdullah dan Suharlina, 2010).

4 Pemupukan

Pemupukan dilakukan dengan menggunakan pupuk kandang satu minggu sebelum penanaman Indigofera dengan dosis 250-300 g/lubang (Abdullah, 2014). Pemupukan NPK mutiara dilakukan pada saat 2 minggu setelah tanam di lahan dengan dosis $240 \mathrm{~kg} / \mathrm{ha}$.

5 Pemeliharaan

Penyulaman tanaman dilakukan untuk mengganti tanaman yang mati atau pertumbuhannya kurang baik dalam 10 hari setelah penanaman. Pemeliharaan tanaman dilakukan untuk pembersihan tanaman dari gulma dan penggemburan tanah kembali 
dengan hati-hati agar tidak merusak sistem perakaran tanaman dan pemupukan.

6 Pemanenan

Pemanenan dilakukan pada saat tanaman mencapai 90 hari setelah tanam. Panen dilakukan dengan memotong tanaman Indigofera pada ketinggian 100 $\mathrm{cm}$ di atas permukaan tanah.

\section{HASIL DAN PEMBAHASAN}

\section{Pengaruh Perlakuan Terhadap Produksi Daun Segar}

Produksi daun segar (gram/tanaman) Indigofera zollingeriana, diperoleh dari produksi segar daun pertanaman percobaan. Pengaruh perlakuan terhadap produksi daun segar I zollingeriana dapat dilihat pada Tabel 1. Produksi daun segar berkisar antara 396,50 gram/tanaman sampai dengan 473,10 gram/tanaman. Hasil ini lebih tinggi dari hasil penelitian Herdiawan dan Sutedi (2012) yang mendapatkan bahwa berat segar daun Indigofera zollingeriana berkisar antara 144,75 sampai 217,41 gram/tanaman serta Sasanya dan Mareen (2016) mendapatkan bahwa berat segar daun berkisar antara 237,08 sampai dengan 275,66 gram/tanaman.

Hasil analisis kerangaman menunjukkan bahwa perlakuan jarak tanam memberikan pengaruh yang berbeda sangat nyata $(\mathrm{P}<0,01)$ terhadap produksi berat segar daun. Uji BNJ menunjukkan bahwa jarak tanam 1,0 m x 1,5 m memberikan produksi berat segar daun yang sangat nyata $(\mathrm{P}<0,01)$ lebih tinggi dari pada jarak tanam $1,0 \mathrm{~m} \times 1,0 \mathrm{~m}$ dan nyata $(\mathrm{P}<0,05)$ lebih tinggi dari pada jarak tanam 1,0 m x $0,5 \mathrm{~m}$. Sedangkan jarak tanam $1,0 \mathrm{~m} \times 1,0$ m memberikan produksi berat segar daun yang berbeda tidak nyata $(\mathrm{P}>0,05)$ dengan jarak tanam $1,0 \mathrm{~m} \times 0,5 \mathrm{~m}$. Tingginya produksi total berat segar tanaman pada jarak tanam 1,0 m x 1,5 m, disebabkan karena pada jarak tanam 1,0 m x 1,5 m belum adanya kompetisi dalam penyerapan unsur hara dan sinar matahari, artinya bahwa belum terjadi kompetisi yang berarti dalam konteks produksi individu. Sesuai pendapat Gardner et al. (1991) bahwa selain faktor genetis tanaman itu sendiri, faktor lingkungan yang berpengaruh antara lain cahaya matahari (penyinaran), kelembaban dan kesuburan tanah. Kelebihan dan kekurangan faktor-faktor tersebut akan berpengaruh terhadap pertumbuhan dan produksi tanaman. Cahaya matahari sangat diperlukan dalam proses fothositesis, dengan banyaknya cahaya yang diterima tanaman maka hasil fotosintesis juga semakin banyak, yang dapat terukur dari pertumbuhan dan produktivitas tanaman. 
Tabel 1. Pengaruh perlakuan jarak tanam terhadap produksi daun segar I zollingeriana (gram/tanaman)

\begin{tabular}{cccc}
\hline \multirow{2}{*}{ Ulangan } & \multicolumn{3}{c}{ Jarak Tanam } \\
\cline { 2 - 4 } & $1,0 \mathrm{~m} \times 0,5 \mathrm{~m}$ & $1,0 \mathrm{~m} \times 1,0 \mathrm{~m}$ & $1,0 \mathrm{~m} \times 1,5 \mathrm{~m}$ \\
\hline 1 & 415,2 & 411,8 & 546,6 \\
2 & 421,0 & 460,0 & 470,2 \\
3 & 434,3 & 457,6 & 485,8 \\
4 & 346,2 & 425,8 & 447,6 \\
5 & 403,4 & 443,6 & 452,6 \\
6 & 359,0 & 504,6 & 435,8 \\
\hline Rataan & $396,50 \pm 35,65^{\mathrm{b}}$ & $450,57 \pm 32,32^{\mathrm{b}}$ & $473,10 \pm 40,08^{\mathrm{a}}$ \\
\hline
\end{tabular}

Keterangan : Angka yang diikuti dengan superskrip dengan huruf yang berbeda menunjukkan perbedaan yang nyata $(\mathrm{P}<0.05)$

\section{Pengaruh Perlakuan Terhadap Produksi \\ Batang Segar}

Produksi batang segar (gram/tanaman) Indigofera zollingeriana, diperoleh dari produksi segar batang per tanaman percobaan. Pengaruh perlakuan terhadap produksi batang segar I zollingeriana dapat dilihat pada Tabel 2. Produksi batang segar berkisar antara 217,87 gram/tanaman sampai dengan 287,23 gram/tanaman. Hasil ini lebih rendah dari hasil penelitian Sasanya dan Mareen (2016) yang

Tabel 2. Pengaruh perlakuan jarak tanam terhadap produksivitas batang segar $I$ zollingeriana (gram/tanaman)

\begin{tabular}{cccc}
\hline \multirow{2}{*}{ Ulangan } & \multicolumn{3}{c}{ Jarak Tanam } \\
\cline { 2 - 4 } & $1,0 \mathrm{~m} \times 0,5 \mathrm{~m}$ & $1,0 \mathrm{~m} \times 1,0 \mathrm{~m}$ & $1,0 \mathrm{~m} \times 1,5 \mathrm{~m}$ \\
\hline 1 & 221,0 & 222,4 & 314,0 \\
2 & 220,2 & 249,4 & 285,2 \\
3 & 223,6 & 239,6 & 303,2 \\
4 & 194,6 & 235,0 & 271,2 \\
5 & 233,6 & 256,0 & 276,0 \\
6 & 204,2 & 269,8 & 273,8 \\
\hline Rataan & $217,87 \pm 15,74^{\mathrm{c}}$ & $245,37 \pm 16,70^{\mathrm{b}}$ & $287,23 \pm 17,55^{\mathrm{a}}$ \\
\hline
\end{tabular}

Keterangan : Angka yang diikuti dengan superskrip dengan huruf yang berbeda menunjukkan perbedaan yang nyata $(\mathrm{P}<0.05)$ 
mendapatkan bahwa berat segar batang berkisar antara 661,25 sampai dengan 716,91 gram/tanaman.

Hasil analisis kerangaman menunjukkan bahwa perlakuan jarak tanam memberikan pengaruh yang berbeda sangat nyata $(\mathrm{P}<0,01)$ terhadap produksi berat segar batang. Uji BNJ menunjukkan bahwa jarak tanam. 1,0 m x 1,5 m memberikan produksi berat batang yang tangat nyata $(\mathrm{P}<0,01)$ lebih tingi dari pada jarak tanam $1,0 \mathrm{~m} \quad \mathrm{x} \quad 1,0 \mathrm{~m}$ dan nyata $(\mathrm{P}<0,05)$ memberikan produksi berat segar batang yang berbeda tidak nyata $(\mathrm{P}>0,05)$ dengan jarak tanam $1,0 \mathrm{~m} \times 0,5 \mathrm{~m}$.

Tingginya produktivitas batang segar tanaman pada jarak tanam 1,0 m x 1,5 m, disebabkan karena pada jarak tanam $1 \mathrm{~m}$ $\mathrm{x}$ 1,5 m kompetisi dalam penyerapan unsur hara dan sinar matahari masih kurang, artinya bahwa belum terjadi kompetisi yang berarti dalam konteks produksi individu. Menurut Harjadi (1993) jarak tanam akan mempengaruhi efisiensi penggunaan cahaya, kompetisi antar tanaman dalam penggunaan air dan unsur hara yang akan mempengurhi hasil apabila tingkat kepadatannya melebihi batas optimum.

\section{Pengaruh Perlakuan Terhadap Produksivitas Bahan Kering Daun}

Produktivitas bahan kering daun $(\mathrm{Kg} / \mathrm{ha})$ merupakan hasil perkalian antara produksi segar daun dengan kandungan bahan kering daun (\%). Pengaruh perlakuan terhadap produksi bahan kering daun I zollingeriana dapat di lihat pada Tabel 3. Produksi bahan kering daun berkisar antara 109,80 gram/tanaman sampai dengan 120.15 gram/tanaman. Hasil ini hampir

Tabel 3. Pengaruh perlakuan jarak tanam terhadap produksi bahan kering daun $I$ zollingeriana (ton/ha/thn)

\begin{tabular}{cccc}
\hline \multirow{2}{*}{ Ulangan } & \multicolumn{3}{c}{ Jarak Tanam } \\
\cline { 2 - 4 } & $1,0 \mathrm{~m} \times 0,5 \mathrm{~m}$ & $1,0 \mathrm{~m} \times 1,0 \mathrm{~m}$ & $1,0 \mathrm{~m} \times 1,5 \mathrm{~m}$ \\
\hline 1 & 126.3233 & 103.8949 & 136.4128 \\
2 & 112.0455 & 112.2639 & 122.8898 \\
3 & 118.0668 & 129.6013 & 142.3268 \\
4 & 100.5389 & 126.7771 & 123.007 \\
5 & 102.342 & 129.4859 & 105.1859 \\
6 & 99.49971 & 138.5349 & 91.13431 \\
\hline Rataan & $109.80 \pm 10.89^{\mathrm{b}}$ & $123.42 \pm 12.80^{\mathrm{ab}}$ & $120.15 \pm 18.17^{\mathrm{a}}$
\end{tabular}

Keterangan: Angka yang diikuti dengan superskrip dengan huruf yang berbeda menunjukkan perbedaan yang nyata $(\mathrm{P}<0.05)$ 
sama dengan hasil penelitian dari Herdiawan dan Sutedi (2012) yang mendapatkan bahwa berat segar batang Indigofera zollingeriana berkisar antara 118,65 sampai dengan 207,06 gram/tanaman. Hasil ini lebih tinggi dari hasil penelitian Sasanya dan Mareen (2016) yang mendapatkan bahwa berat kering daun berkisar antara 83,85 sampai dengan 98,90 gram/tanaman

Hasil analisis kerangaman menunjukkan bahwa perlakuan jarak tanam memberikan pengaruh yang berbeda tangat nyata $(\mathrm{P}<0,01)$ terhadap produksi bahan kering daun .Uji BNJ menunjukkan bahwa jarak tanam $1,0 \mathrm{~m} \times 1,0 \mathrm{~m}$ memberikan produksi berat kering yang tangat nyata $(\mathrm{P}<0,01)$ lebih tingi dari pada jarak tanam $1,0 \mathrm{~m} \times 0,5 \mathrm{~m}$ dan berbeda tidak nyata $(\mathrm{P}>0,05)$ memberikan produksi bahan kering daun dengan jarak tanam 1,0 m x1,5 m.
Tingginya produktivitas bahan kering daun tanaman pada jarak tanam $1,0 \mathrm{~m}$ x 1,0 m, di sebabkan karena pada jarak tanam 1 $\mathrm{m} \times 1,0 \mathrm{~m}$ tingkat pertumbuhan berada pada titik optimum, kompetisi dalam penyerapan unsur hara dan sinar matahari masih kurang, artinya bahwa belum terjadi kompetisi yang berarti dalam konteks produksi individu. Harjadi (1993) menyatakan bahwa jarak tanam merupakan salah satu faktor yang sangat mempengaruhi pertumbuhan dan produksi tanaman yang optimal.

\section{Pengaruh Perlakuanyan Terhadap Produksi Bahan Kering Batang.}

Produksi bahan kering batang $(\mathrm{Kg} / \mathrm{ha})$ merupakan hasil perkalian antara produksi segar batang dengan kandungan bahan kering batang (\%). Pengaruh perlakuan terhadap produksi bahan kering batang I zollingeriana dapat di lihat pada

Tabel 4. Pengaruh perlakuan jarak tanam terhadap produksi bahan kering batang $I$ zollingeriana (ton/ha/thn)

\begin{tabular}{cccc}
\hline \multirow{2}{*}{ Ulangan } & \multicolumn{3}{c}{ Jarak Tanam } \\
\cline { 2 - 4 } & $1,0 \mathrm{~m} \mathrm{x} \mathrm{0,5m}$ & $1,0 \mathrm{~m} \mathrm{x} \mathrm{1,0m}$ & $1,0 \mathrm{~m} \mathrm{x} \mathrm{1,5m}$ \\
\hline 1 & 98.61981 & 77.05817 & 102.4259 \\
2 & 64.8841 & 90.96252 & 78.70419 \\
3 & 63.25241 & 80.58406 & 110.458 \\
4 & 62.36552 & 81.5064 & 101.706 \\
5 & 68.73234 & 68.75274 & 103.2795 \\
6 & 59.4317 & 74.0801 & 63.70597 \\
\hline Rataan & $69.54 \pm 14.56^{\mathrm{b}}$ & $78.82 \pm 7.54^{\mathrm{ab}}$ & $93.54 \pm 17.93^{\mathrm{a}}$ \\
\hline
\end{tabular}

Keterangan : Angka yang diikuti dengan superskrip dengan huruf yang berbeda menunjukkan perbedaan yang nyata $(\mathrm{P}<0.05)$ 
Tabel 4. Produksi bahan kering batang berkisar antara 69,54 gram/tanaman sampai dengan 93,54 gram/tanaman. Hasil ini lebih tinggi hasil penelitian dari Suharlina dan Abdullah (2012) yang mendapatkan bahwa berat bahan kering batang indigofera berkisar 23,92 sampai dengan 28,84 gram/tanaman, namun hasil ini lebih rendah dari hasil penelitian Sasanya dan Mareen (2016) yang mendapatkan bahwa berat kering batang berkisar antara 244,35 sampai dengan 318,64 gram/tanaman. Hasil analisis kerangaman menunjukkan bahwa perlakuan jarak tanam memberikan pengaruh yang berbeda nyata $(\mathrm{P}<0,05)$ terhadap produksi bahan kering batang $\mathrm{Uji}$ BNJ Menunjukkan bahwa jarak tanam 1,0 $\mathrm{m} \times 1,5 \mathrm{~m}$ memberikan produksi berat kering batang nyata $(\mathrm{P}<0,05)$ lebih tinggi dari pada jarak tanam $1,0 \mathrm{~m} \times 0,5 \mathrm{~m}$, dan berbeda tidak nyata $(\mathrm{P}>0,05)$ dengan jarak tanam 1,0 m x 1,0 m. Sedangkan jarak tanam $1,0 \mathrm{~m} \quad \mathrm{x} \quad 1,0 \mathrm{~m}$ memberikan pengaruh yang berbenda tidak nyata. $(\mathrm{P}<0,05)$ sedangkan jarak tanam 1,0 m x 0,5 $\mathrm{m}$.

Tingginya produksi bahan kering tanaman pada jarak tanam $1,0 \mathrm{~m} \times 0,5 \mathrm{~m}$ di sebabkan karena tanaman yang lebih banyak,hal ini sesuai dengan pendapat (Slanev dan Enchv, 2014) bahwa meningkatnya kepadatan tanaman akan meningkatkan produksi bahan kering tanaman. Jarak tanam mempengaruhi pertumbuhan tanaman. Jarak yang dekat (Kepadatan yang lebih tinggi) akan meningkatkan persaingan unsur hara, air dan sinar matahari kepadatan yang menigkat juga akan mempengaruhi suhu dan kelembaban lingkungan. Menurut Tarigan (2009) rataan produksi bahan kering I. zolingeriana dengan umur panen 30 hari yaitu 16,26 ton/ha/tahun, Umur 60 hari 21,18 ton/ha/tahun, sementara umur panen 90 hari yaitu sebesar 28,33 ton/ha/tahun.

\section{KESIMPULAN}

Jarak tanam 1,0 meter $\mathrm{x} 1,5$ meter adalah yang terbaik karena memberikan produksi daun segar per tanaman, batang segar pertanaman, dan produksi bahan kering batang pertanaman yang tertingi.

\section{DAFTAR PUSTAKA}

Abdullah, L. dan Suharlina. 2010. Herbage yield and quality of two vegetative parts of indigofera at different times of first regrowth defoliation. Media Peternakan 33(1): 44-49.

Abdullah, L. 2014. Prospektif agronomi dan ekofisiologi Indigofera zollingeriana sebagai tanaman penghasil hijauan pakan berkualitas tinggi. Pastura 3(2):79-83.

Anis, S.D., M.M. Telleng, Ch.L. Kaunang, U. Paputungan, dan C.J Sumolang. 2019. Preliminary evaluation on morphological respons of Indigofer 
zollingeriana tree legumes under different cropping pattern grown at 12 weeks after planting underneath mature coconuts. Journal of Livestock Research for Rural Development 31(9).

Gardner, F.P., R.B. Pearce, dan R.L. Mitchell. 1991. Fisiologi Tanaman Budidaya. Terjemahan Herawati Susilo. Universitas Indonesia Press. Jakarta. 428 hal.

Harjadi, S.S. 1993. Pengantar Agronomi. Jakarta: Gramedia Pustaka Utama.

Herdiawan, I. dan E. Sutedi. 2012. Produktivitas tanaman pakan Indigofera sp. pada tingkat cekaman kekeringan dan interval pemangkasan berbeda. JITV 17(2): 161-167.

Sasanya, V.S. dan A. Mareen. 2016. Stability analysis of selected mutants of Indian indigo (Indigofera tinctoria L.). Journal of Applied and Advanced Research 1(3): 25-30.

Slanev, K. dan S. Enchev. 2014. Influenceof veriety and density on crop productivity of sorgum sudan grass hybrids in flowering stage. BJAS. 20(1): 182185.

Steel, R.G.D. dan J.H. Torrie. 1995. Prinsip dan Prosedur Statistika: Suatu Pendekatan Biometrik. Gramedia, Jakarta.

Suharlina dan L. Abdullah. 2012. Peningkatan produktivitas Indigofera $s p$. sebagai pakan hijauan berkualitas tinggi melalui aplikasi pupuk organik cair: Produksi hijauan dan dampaknya terhadap kondisi tanah. Pastura 1(2): 39-43.

Tarigan A. 2009. Productivity and utilization of Indigofera sp. as goat's feed obtained from different interval and intensity of cutting. Thesis. Bogor Agricultural University.

Telleng, M. M. 2017. Penyediaan pakan berkualitas berbasis sorgum dan indigofera dengan pola tanam tumpang sari. Disertasi. Sekolah Pascasarjana, Institut Pertanian Bogor.

Telleng, M., K.G. Wiryawan, P.D.M.H. Karti, I.G. Permana, and L. Abdullah. 2016. Forage production and nutrient composition of different sorghum varieties cultivated with Indigofera in intercropping system. Media Peternakan 39(3): 203-209.

Telleng, M., K.G. Wiryawan, P.D.M.H. Karti, I.G. Permana, and L. Abdullah. 2017. Silage quality of rations based on in situ sorghum-indigofera. Pak. J. Nutr. 16(3): 168-174. 